\title{
Selected aspects of technological innovations management in district heating companies
}

\author{
Aleksandra $\mathrm{Rak}^{1, *}$ \\ ${ }^{1}$ Department of Production and Safety Engineering, Czestochowa University of Technology, Armii \\ Krajowej 19 B, 42-200 Czestochowa, Poland, EU
}

\begin{abstract}
The accession of Poland to the EU results in the realization of EU directives, including the field of energy efficiency and $\mathrm{CO}_{2}$ emissions. The regulations oblige enterprises that produce and distribute heat to technical activities involving the use of existing heat sources and modernization of thermal networks, as well as economic and environmental optimization of the heat supply process. The implementation of these projects requires a change in the way the energy sector is managed and thoroughly restructured by implementing and applying technological and product innovations. The article discusses the legal and environmental conditions of the heat market in Poland, the key challenges for the heating industry and selected innovations in heating companies regarding two areas: technical infrastructure and management of the heat production and transmission.
\end{abstract}

\section{Introduction - the innovative activity}

Changes in the conditions of the company's operation result from the influence of different factors, e.g. economic, social, political, demographic and technological. Among them the most important are: diversification of clients' needs, increase of competitiveness, increasing influence of knowledge and information and development of IT technology [1].

The concept of innovation was introduced for the first time by an Austrian economist J. Schumpeter in the literature of economics at the beginning of the 20th century. However, the paradigm of economy that based on knowledge was created in the 1990s and, as a result of which, the theory of innovation management was created. Five main areas of innovation can be distinguished - product, service, process, business process and business model innovation [2]. In general, companies can make changes that apply to all the areas and levels of their operations [2-4]. However, companies need to identify which areas are important for them.

\section{The technological innovation management process}

Nowadays, innovation management can be defined as seeking, based on possessed resources, such types of innovations that make the innovation process more effective in confronting the challenges placed before the organization by the market, competition and the client. It includes the selection of new techniques, technology, work organization, issues of acquiring new solutions and the possibilities of their use, considering legal, economic and financial, administrative, structural and process, environmental and strategic matters. Multidimensionality and complexity of innovative processes requires a systematic approach

\footnotetext{
*Corresponding author: aleksandra.rak@wz.pcz.pl
} 
to managing this area of activity, including all levels of business management, i.e. the level of strategic and operational management, personnel, organizational structures and processes $[1,2,5,6]$.

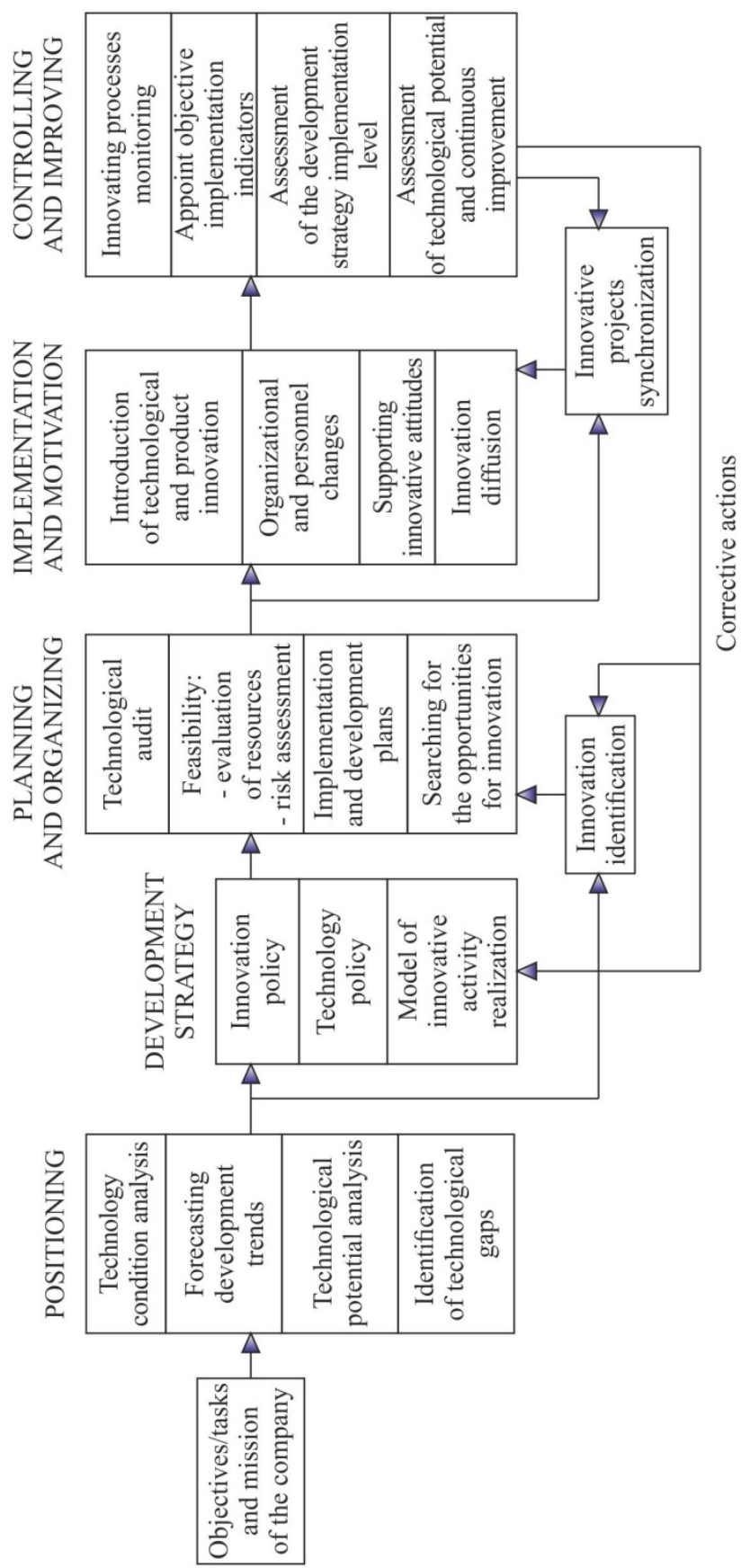

Fig. 1. Model of technological innovation management process in the companies. 
Innovation management in companies includes the following activities aimed at effective achievement of the assumed objectives [3]:

- change of the company's strategy,

- making decisions in the field of innovative activity of the enterprise,

- organization, including searching for opportunities for innovation, financing innovative activities, implementation of research and development projects, ensuring the security of intellectual property,

- controlling the innovative activity of the company,

- $\quad$ supporting innovative attitudes by building competences for innovation and developing organizational culture.

There are many external and internal factors that have a significant impact on the innovation management. These determinants are divided into internal or organizational (related to the company) and external ones resulting from the enterprise environment. External determinants are primarily: the market and demand shaping, competition, globalization and regionalization, technological progress, the functioning and development of industry. However, the determinants of innovation management at the organizational level are the result of changes taking place in the global economy, which significantly change the way in which innovative activity is implemented and formed the development of innovative potential. The main factor determining the effective management at the level of the organization is the skillful adjustment of material and immaterial resources (knowledge, competencies of employees) of the company to achieve the assumed objectives [1].

In the literature on the subject, management of technological innovations has not been precisely defined. This concept can be derived from the combination of technological innovations definitions (technical, process) and models of innovation management described in the literature. The management of technological innovations contains all management activities that decide about innovation and technology policy, objectives and responsibilities and their realization by operation, such as: planning, providing resources, organizing and controlling the development of technology, improving innovation in the processes of their implementation and exploitation [7]. In the model approach, the technological innovation management process can be presented in the way shown in Figure 1. Important elements of this process are building the innovation strategy and implementation and development plans based on the analysis technology condition, the technological potential of the company and forecasted development trends. The decision of innovations implementation should be preceded by a technology audit and resource and risk assessment. In the phase of innovation implementation it is important to monitor the innovation processes, set indicators of realization objective and evaluate the implementation of the company's development strategy.

\section{Determinants and trends in heating systems development}

The development of heating systems is influenced by actions resulting from the energy policy of the country, implemented under the European Union regulations. The main directions of this policy, relating to heating sector in Poland are [8]:

- improving energy efficiency and increasing the efficiency of systems,

- balanced development and increased use of renewable energy sources,

- energy security and development of competitive fuel and energy markets,

- limiting the impact on the environment

The increase in the energy efficiency is a priority binding for the implementation of other objectives of the Polish energy policy, which was reflected in the adoption of the law on energy efficiency in 2011 [9]. The Directive 2012/27 / EU on energy efficiency is very 
important for the district heating development [10]. It defines an "efficient heating and cooling system" as a system in which at least $50 \%$ of energy from renewable sources or waste heat is used for heat or cold production, or at least $75 \%$ of heat from cogeneration, or in at least $50 \%$ of the combination of such energy and heat. This implies supporting the use and expansion of existing infrastructure, heat sources and heating networks, in terms of their adaptation to the use and development of high-efficiency cogeneration, including waste heat and energy from renewable sources [11].

District heating systems must guarantee the continuity of heat supply to consumers, despite of the influence of external factors, usually independent of the producer, and internal ones comprising its management as well as the processes of producing and distributing heat [12]. Production and supply system heat is a complex process, which should take into account a number of problems in the fields of technology, ecology and economy, as well as the existence of a number of threats. The basic factors affecting the directions and opportunities for the development of heating systems are given in Table 1.

Table 1. Factors influencing the directions and possibilities of development of heating systems.

\begin{tabular}{|c|c|}
\hline Internal factors & External factors \\
\hline 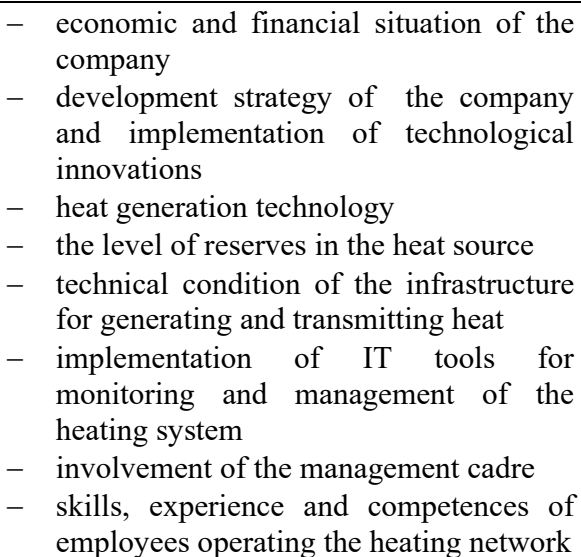 & $\begin{array}{l}\text { - } \text { macroeconomic conditions } \\
- \text { technical and environmental requirements } \\
- \text { programs and funds promoting the } \\
\text { improvement of energy efficiency } \\
-\quad \text { financial support of the state for } \\
\text { innovative activity } \\
- \text { development of energy-saving } \\
\text { construction technologies } \\
- \text { development of prosumer energy and } \\
\text { micro-generation } \\
- \text { climatic conditions } \\
-\quad \text { reliability of fuel supply and electricity } \\
- \\
\text { fuel price level (impact on costs and } \\
\text { profitability of operations) }\end{array}$ \\
\hline
\end{tabular}

\section{Technological innovations in district heating companies}

Fulfilment of priorities, regarding the improvement of energy safety and efficiency as well as ecological indicators in the area of heat supply, requires comprehensive modernization and implementation of innovative technological solutions. These activities are necessary in all segments creating the local heat market [11-14]:

- heat production - development of cogeneration and trigeneration systems (combined heat and power production), change of energy production technology, implementation of fuels with lower environmental load, heat storage,

- $\quad$ in the area of heating networks - construction of intelligent heating networks (smart grid), exchange on pre-insulated pipes networks, automation systems, monitoring and management of network operation, hydraulic regulation, new regulatory tables,

- $\quad$ construction and installation systems at the recipients - implementation of the lowenergy construction standard, thermo-modernization of buildings, modernization of nodes (weather sensors and shut-off valves), individual heat consumption accounting systems, increased use of renewable energy sources.

Realization of technology improvement processes as well as the introduction of technological innovations in district heating enterprises are dictated by market needs 
(reduction of ordered power, lower costs for recipient) and competition pressure (prosumer energy and RES development). Improvement of heat generation technology in cogeneration and trigeneration systems requires large investment expenditures, which is why innovative changes are most often inducted. Technological innovation in district heating companies concerns two areas: technical infrastructure and management of the heat production and transmission system [12]. Typical technological innovations implemented in heating enterprises are given in Table 2.

Table 2. Typical technological innovations in heating companies.

\begin{tabular}{|l|l|}
\hline \multicolumn{1}{|c|}{ Technical infrastructure } & \multicolumn{1}{|c|}{$\begin{array}{c}\text { Managing the production system } \\
\text { and heat transfer }\end{array}$} \\
\hline$-\begin{array}{l}\text { modification of the heat and electricity } \\
\text { production method, }\end{array}$ & $-\begin{array}{l}\text { market models for the regulation of heat } \\
\text { supply in heating systems, }\end{array}$ \\
$-\begin{array}{l}\text { implementation of fuels with a lower } \\
\text { environmental burden, }\end{array}$ & $\begin{array}{l}\text { using IT tools to manage the network } \\
\text { operation, taking into account weather } \\
\text { conditions, }\end{array}$ \\
$-\begin{array}{l}\text { applying new technical solutions in the } \\
\text { form of pre-insulated pipes with an } \\
\text { alarm system. }\end{array}$ & $\begin{array}{l}\text { use of teletransmission systems for } \\
\text { monitoring and controlling the operation } \\
\text { of the network. }\end{array}$ \\
\hline
\end{tabular}

Innovative solutions in the production infrastructure concern, i.a. changes in the method of heat and electricity production from classical coal combustion to combustion and fluid gasification or oxygen combustion technologies (TST) and the introduction of fuels with lower environmental load (dust, $\mathrm{CO} 2, \mathrm{SO} 2$ and NOx emission levels). In the transmission infrastructure are applied new technical solutions in the form of multilayer pipe systems insulated with PUR foam and placed as a pipe assembly together with an alarm system in a common casing $[12,13]$.

In the area of management of heat production and transmission systems, technological innovations are based on the use of IT tools and teletransmission systems. The implementation of modern IT systems requires the installation of heat network metering and data transmission systems for further analysis and processing. The use of distributed control systems and SCADA type packages enables visualization of the heating system operation and remote control of the operation of individual devices. Visualization systems facilitate current operation and improve the economic efficiency of network management $[12,15]$.

The presented range of innovations possible to introduce is so extensive, that in the conditions of limited material and financial resources, the process of their implementation must be spread over time.The priorities result from the adopted development strategy, which depends on the market position and potential of a given heating enterprise. Due to the achieved effects, mainly economic and environmental, large heating companies in Poland initially has introduced technological innovations in the area of generation, while small and medium-sized companies were focused on improving heat transfer (11).

The introduction of market models for the supply of heat, based on technical parameters and a cost account, enables improving the operational efficiency of the heating system and optimization of investment processes, both on the scale of a single company and in the whole sector. Such a comprehensive approach to the innovation management process in heating must include not only technological aspects, but also organizational solutions and decision-making processes [18].

The implementation of software packages dedicated to the heating sector not only provides current control and control of the operation of heating systems, but also enables modelling of static and dynamic state occurring in real conditions. Advanced programs for 
modeling and optimizing the operation of heating networks taking into account weather conditions are available on the market, such as Bentley SisHYD and TERMIS [15].

\section{Summary}

The changes taking place in the national economy, the requirements of the climate and energy policy, trends in heat demand and the increase in energy security force heating companies to induct modern and innovative technologies as well as a new way of business management. Management of technological innovations in heating is an important element of the development strategy of the companies in this sector, that determines the competitive position as well as the operational and economic efficiency. It should be emphasized that the introduction of new technical solutions and technological innovations also results in organizational and personnel changes, consisting in the formation of interdisciplinary teams of employees with high qualifications and competences.

\section{References}

1. P. Mielcarek, Procesy zarzadzania innowacjami w przedsiębiorstwach przemysłowych (2016)

2. K. Goffin, R. Mitchell, Innovation Management: Effective Strategy and Implementation (2017)

3. M. Karlik, Zarządzanie innowacjami w przedsiębiorstwie. Poszukiwanie i realizacja nowatorskich projektów (2014)

4. J. Tidd, J. Bessant, Management Innovation. Integrating Technological, Market and Organizational Change (2009)

5. K. Szatkowski, Zarzadzanie innowacjami i transferem technologii (2016)

6. M.A. White, G.D. Bruton, The Management of Technology\&Innovation. A Strategic Approach (2011)

7. J. Łunarski, Innowacje technologiczne w przedsiębiorstwach. Projektowanie, wdrażanie i użytkowanie (2016)

8. Polityka energetyczna Polski do 2030 roku. Załącznik do obwieszczenia Ministra Gospodarki z dnia 21 grudnia 2009 roku (MP z 2010, nr 2, poz. 11)

9. Ustawa z dnia 15 kwietnia 2011 r. o efektywności energetycznej (Dz.U. z 2011 r., nr 94, poz. 551)

10. Dyrektywa Parlamentu Europejskiego i Rady 2012/27/UE z 25 października 2012 roku w sprawie efektywności energetycznej, ... (Dz.U. UE L 315 z 14.11.2012 r.)

11. M. Turski, R. Sekret, Rynek Energii, 4(119), 27-34 (2015)

12. A. Rak, R. Kucęba, R. Sekret, Techniczne $i$ materialne aspekty bezpieczeństwa 102-113 (2017)

13. A. Jachura, R. Sekret, Instal, 7-8, 7-11 (2013)

14. T.M. Mróz, Ciepłownictwo, Ogrzewnictwo, Wentylacja, 10, 403-407 (2012)

15. A. Rak, Zeszyty Naukowe UE w Katowicach, 308, 115-127 (2016)

16. U. Sarma, G. Bazbauers, Energy Procedia, 84, 401-407 (2016)

17. K. Sipilä, J. Pietiläinen, A. Nuorkivi, The building level substation - the innovation of district heating system (2016)

18. J. Birkinshaw, G. Hamel, M.J. Mol, Management innovation (2010) 